\title{
TITLE:
}

\section{THE ZOOGEOGRAPHICAL ASPECTS OF THE JAPAN SEA -PART II-}

AUTHOR(S):

Nishimura, Saburo

CITATION:

Nishimura, Saburo. THE ZOOGEOGRAPHICAL ASPECTS OF THE JAPAN SEA -PART II-. PUBLICATIONS OF THE SETO MARINE BIOLOGICAL LABORATORY 1965, 13(2): 81-101

\section{ISSUE DATE:}

1965-08-30

URL:

http://hdl.handle.net/2433/175402

RIGHT: 


\title{
THE ZOOGEOGRAPHICAL ASPECTS OF THE JAPAN SEA PART II ${ }^{13}$
}

\author{
SABURO NISHIMURA
}

Seto Marine Biological Laboratory, Sirahama

With Text-figures $16-23$

\section{CONTENTS}

3. Peculiarities of Animal Distribution in the Japan Sea (continued) ......... 81

3. 7. Plankton Production and Distribution in the Japan Sea ............... 81

3.8. Seasonal Migrations of the Temperate and Subtropical Nektonic Animals.

\section{Peculiarities of Animal Distribution in the Japan Sea (continued)}

\subsection{Plankton Production and Distribution in the Japan Sea}

The production and distribution of plankton which are to affect the distribution and migration of the animal communities of the higher trophic rank are themselves influenced not only by hydrographical and meteorological conditions but also by the composition of the plankton itself, by the different ecological properties of partaking plankton producers and herbivores, and by their different combinations (HEINRICH 1961, 1962). Thus, in discussing the aspects of production and distribution of plankton in any water environment, it is of an essential importance to pay a full attention to the ecological properties of the plankton species involved.

One of the most remarkable features of the zooplankton production and distribution in the Japan Sea is the conspicuous mass rising from deeper layers and subsequent drift to the coastal waters in the spring season of certain large, mostly bathypelagic, zooplankters such as Calanus plumchrus, C. cristatus, Metridia pacifica (Copepoda), Euphausia pacifica, Parathemisto japonica (Amphipoda), Sagitta elegans and Aglantha digitale (Trachymedusa). Of these, the first two copepods are most important in quantity and in the extent of distribution (Meshcheryakova 1960). In offshore regions around the polar front, Thysanoessa longipes (Euphausiacea) and Euprimno macropa (Amphipoda)

1) Contributions from the Seto Marine Biological Laboratory, No. 436.

Publ. Seto Mar. Biol. Lab., XIII (2), 81-101, $1965 . \quad$ (Article 4) 
also play respectively an important bio-economical role (FUKATAKI 1960a; FuKATAKI et al. 1961).

The annual maximum of macroplankton in most areas in the Japan Sea is brought forth by the outburst of these zooplankters. Meshcheryakova (1960) observed that the outburst is most prominent in the central part of the sea. These zooplankters are then drifted ashore toward the west coasts of Honshu and Hokkaido in large mass and there support a great deal of plankton feeders (Nishimura \& Oкаснi 1957; Nishimura 1959b). Their nearshore occurrences are often made in so drastic scale to form discolored patches even observable from land by naked eye (MотоDA 1944). Calanus plumchrus is particularly noteworthy: an estimation of the abundance of this copepod has been made by NAKaI (1942a, b) on the data of vertical hauls by a plankton net with a $60-\mathrm{cm}$ mouth diameter and stretched with the gauze No. 3 that about 10.0 million tons or $63 \%$ (misprinted as $93 \%$ in NAKAI 1942b) of 15.6 million tons of macroplankton in the upper $150 \mathrm{~m}$ in the west of the line connecting Cape Povorotnui of Maritime Province and Niigata of Honshu produced in the term May to July 1940 were possibly occupied by Calanus plumchrus alone; and Meshcheryakova (1960) found that 75 to $90 \%$ of the total zooplankton biomass distributed in the upper $100 \mathrm{~m}$ in the central part of the Japan Sea during the seasons May to early July of 1950 to 1954 was occupied by the same copepod. No doubt there were abundant Calanus cristatus, Thysanoessa longipes, Parathemisto japonica, Euprimno macropa, etc. in addition; most of them, however, might have escaped the net because of their large swimming ability. According to Fukataki (1960a) and Fukataki et al. (1961), the pink salmon Oncorhynchus gorbuscha caught in some offshore regions in March to June are often found with the stomach filled of the above-named plankton animals.

It must be further noticed that Calanus plumchrus and $C$. cristatus constituting the most important part of the spring outburst in the shallower layers are all composed of immature females, mostly in the 5th copepodite stage immediately before the sexual maturity, and partly in the 3rd or 4th copepodite stage, but none in the adult stage. Adult females and males of these copepods live in great depths. YAMADA (1938) found for the first time the adult individuals of $C$. plumchrus in the stomach of Theragra chalcogramma, a bathypelagic gadoid caught from the bottom off northeast Korea and Motod A (1944) found them again in the stomach content of the same fish from the deep water off west Hokkaido. Meanwhile, NAKAI (1942b, c) discovered large populations of adult females and males of $C$. plumchrus inhabiting the 200-2000 $\mathrm{m}$ depths almost in every part of the Japan Sea and moreover (NAKAI 1942c) succeeded to capture eggs and nauplii of $C$. cristatus together with their adults from the $1000-2000 \mathrm{~m}$ layer off northeast Korea. It is another 
interesting fact that these calanoids do not feed in the adult stage, thus the masticatory part of their mandible is reduced (CAMPBELL 1934; BeKLEMISHeV 1954); and it is also very peculiar that they breed in winter and their earlier developments are finished prior to the spring phytoplankton bloom (HEINRICH 1961), forming a striking contrast to the cases of the intensive adult-feeding species such as Calanus finmarchicus in the North Atlantic and C. acutus and C. propinquus in the Antarctic Ocean. It is supposed that the above-mentioned Far Eastern copepods, having fed intensively on phytoplankton during larval stages and stored a large amount of fat in the body, descend to the deeper layers when they reach the later period of the 5th copepodite stage in early summer to autumn, spend the winter there without feeding, and, molting into the adult stage, breed in or just prior to late winter (Bogorov \& Vinogradov 1955; Heinrich 1961, 1962). The larval population thus produced may rise to the shallower layers and then be drifted and dispersed throughout the sea, grazing phytoplankton just in the vernal bloom and growing rapidly up to the 5th copepodite stage. Meshcheryakova (1960) estimated that Calanus plumchrus breeds in February to middle April in the northwestern part of the Japan Sea and one to one and half months earlier in the southeastern part. A more or less similar life cycle may be seen for many other bathypelagic zooplankters of the Japan Sea including Parathemisto japonica, Thysanoessa longipes, Euprimno macropa, Sagitta elegans and Aglantha digitale (Metridia pacifica may be an exception, both youngs and adults of this copepod being found abundantly in nearshore waters): it is well known that the populations of these members found in the nearshore waters in the spring outburst are composed of smaller immature individuals and the larger or adult individuals are collected only from deep layers in the offshore region.

A short note will be given next on the seasonal cycle of plankton production in the Japan Sea, although the available data are rather scanty. Motoda \& ANRAKU (1958) ever stated that two distinct peaks of phytoplankton production are discernible in the Japan Sea, respectively in spring and autumn. However, during my observations extending from 1954 to 1962 in the middle and southeastern parts of this marginal sea, the autumnal bloom was always indiscernible there; instead, from October to December or January, the plankton standing crop was poorest throughout the year. The vernal phytoplankton bloom, on the other hand, was very conspicuous; the principal constituents were diatoms such as Coscinodiscus wailesii, C. granii, Hemidiscus hardmanianus, Rhizosolenia spp. (especially styliformis var. latissima), Chaetoceros spp., Biddulphia sinensis, etc. Of these, the first ${ }^{23}$ is most note-

2) This diatom had been referred to Coscinodiscus janischii or C. gigas by many Japanese planktologists before KoKUBO (1952) assigned it to $C$. wailesii previously known from Puget Sound, Washington, and off southern California. See also TAKANO (1957). It is GAIL (1950) who recorded this species for the first time in the list of phytoplankton of the Japan Sea. 
worthy for its large size and prevailing occurrence. It is not rare that the bucket and posterior part of the plankton net are packed tightly almost exclusively with this diatom at the peak of its abundance. The vernal bloom extends from January-February to March-April in the southeastern part of the Japan Sea; and in later stages of this bloom it is often observed that a massive quantity of Coscinodiscus wailesii, half-disintegrated, is gradually sinking to deeper layers (Meshcheryakova 1960; my own observations in 1957 and other years), suggesting that the spring plankton production in this region of the sea is "unbalanced" by the term of Cushing (1959), that is, the majority of the diatom population decays without being used by herbivorous zooplankters. There are two points of special interest in the specific composition of the vernal blooming phytoplankton in this region of the Japan Sea : first, such an array of the dominant species as listed above is essentially the same as observed in the Kuroshio region in the Pacific like around Izu-Oshima south of Tokyo (TAKANO 1954) and quite different from that found in the northern and northwestern parts of the Japan Sea (see below); second, most of these diatoms, i.e. Coscinodiscus wailesii ${ }^{3}$, Hemidiscus hardmanianus, Rhizosolenia styliformis var. latissima, Rh. bergonii, Biddulphia sinensis, etc. are subtropical or tropical oceanic species, and this appears rather strange, as the vernal bloom occurs in the season of the lowest water temperature in the southeastern part of the Japan Sea.

Reliable data show that there is but a single main peak of phytoplankton propagation in the year in the western and northwestern parts of the Japan Sea, too, though one or more much lesser peaks may be recognized in sum. mer or autumn (Meshchery akova 1956, 1960; Heinrich 1961). The predominant elements of the vernal bloom in these northerly waters are Coscinodiscus oculus-iridis and centralis var. pacifica, Thalassiothrix longissima, Thalassiosira excentrica and nordenskiöldii, Corethron hystrix, Chaetoceros decipiens, subsecundus (=diadema), atlanticus and convolutus, Rhizosolenia hebetata f. hiemalis and $\mathrm{f}$. semispina, etc., mostly arctic or north-boreal oceanic species (AIKAWA 1936; Gail 1950; Iizuka \& Tamura 1953; Shimomura 1960a; Meshchery akova 1960; BeLYAEva 1961), and thus the qualitative and quantitative composition of the

3) Coscinodiscus wailesii has generally been regarded as a north temperate or boreal species (cf. Takano 1954; KoKubo 1955; etc.). This diatom, however, is quite absent in the northern Japan Sea, the Okhotsk and Bering Seas (CupP 1937; TAKANo 1959; SmIRnova 1959; SEMINA \& ZhUZE 1959; Meshcherya Kova 1960), while it is abundant in the Japanese waters, sometimes predominant even in such subtropical regions as around Izu-Oshima in the water temperature of $16^{\circ}$ to $17^{\circ} \mathrm{C}$ (TAKANo 1954). CUPP (1943) mentions that it is not uncommon off southern California. Thus, I am inclined to the view of some Russian planktologists treating this species as a subtropical element. The data of TAKANo (1955) show that it occurs in the temperature as high as $26^{\circ} \mathrm{C}$. 
blooming phytoplankton in this region are generally resembling that found in the Okhotsk Sea (Smirnova 1959). Moreover, it is a remarkable fact that Coscinodiscus wailesii, the most prominent vernal blooming species in the southeastern region, never occurs in these northerly waters; and there seem

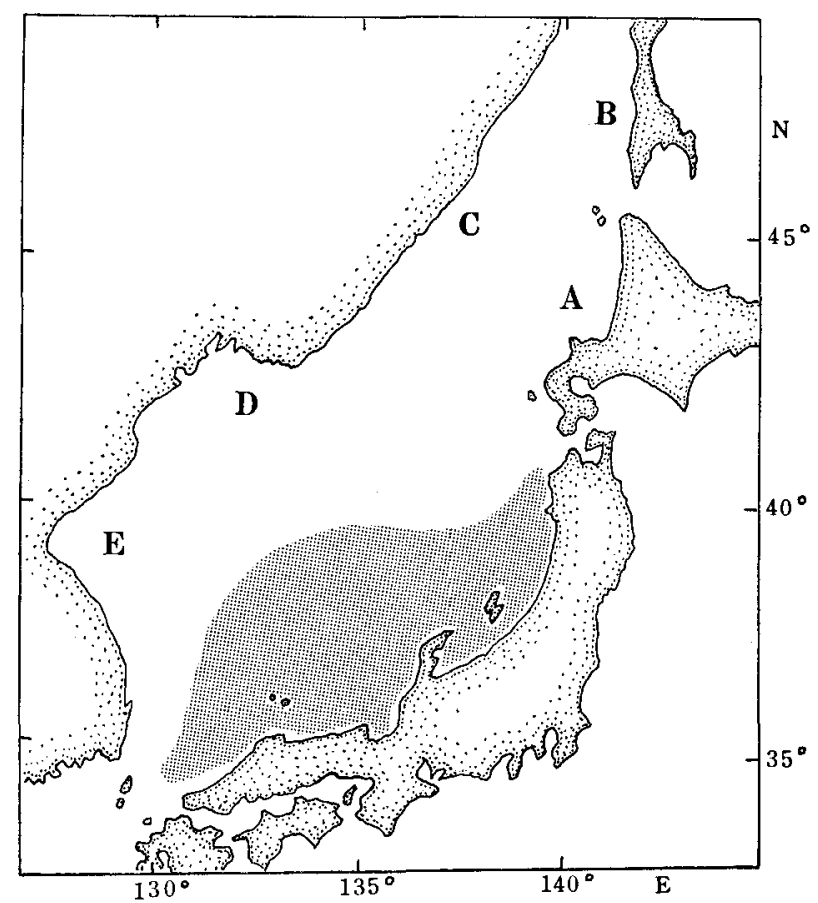

Fig. 16. Occurrence area (hatched) of Coscinodiscus wailesii during the vernal phytoplankon bloom in the Japan Sea ; other important phytoplankters partaking in the vernal bloom in this area are Coscinodiscus granii and centralis var. pacificus, Hemidiscus hardmanianus, Rhizosolenia styliformis var. latissima, Biddulphia sinensis, etc. Predominent blooming phytoplankters in other areas of the Japan Sea are Chaetoceros spp., especially decipiens, in Area A; Thalassiosira nordenskiöldii in Area B; Coscinodiscus oculus-iridis in Area $\mathrm{C}$; C. oculus-iridis and centralis var. pacificus, Chaetoceros atlanticus and Rhizosolenia hebetata f. hiemalis in Area D; and Coscinodiscus concinnus and centralis var. pacificus in Area E.

to be evidences that the predominant phytoplankton species in the vernal bloom in these norherly waters are somewhat different in different regions (Fig. 16). The bloom cccurs much later in the northerly waters than in the southeastern region, from the end of March or the beginning of April through 
May, namely, after the season of the annual minimum water temperature ${ }^{4}$.

Succeeding to the vernal bloom, there occurs the previously-mentioned rapid grow th of the zooplankton biomass. The rising and subsequent shoreward drift of these bathypelagic plankters take place almost simultaneously throughout a wide range (or slightly later in the higher latitudes) in the Japan Sea except of its southernmost area, but there is a marked trend that the period is of a longer duration in the northern area than in the southern area: it occurs in middle March to May in Wakasa Bay, west Honshu (FURUHASH et al. 1952), late March to middle May around Sado Island (Nishimura 1958e, 1959b), April to late May in Mutsu Bay at the northern end of Honshu (Kokubo 1950a, 1950b, 1952), March or April to June in Oshoro Bay (Tanaka 1947; Anraku 1953) and middle or late Aplil to June (?) in the inner part of Ishikari Bay (Irzuka et al. 1951; Iızuka \& TAmura 1963), both on the west coast of Hokkaido, and April to July off southwest Sakhalin and in Peter the Great Bay (Brodsky 1941; Meshcheryakova 1954, 1960; Ponomareva 1959 ; Ivleva 1960). The phenomenon is not known in the southernmost part of the Japan Sea, for instance, off the western part of San'in District and west Kyushu (Enomoto 1957; TanaKa \& Koga 1958; Senta 1958).

In the southeastern part of the Japan Sea, the above-mentioned bathypelagic zooplankters gradually diminish toward the end of May or early June and are replaced by warm-water or south-boreal neritic elements such as Calanus sinicus ${ }^{5}$, Paracalanus parvus, Oithona nana, Corycaeus affinis $(=C$. japonicus), Podon leuckardti, Evadne nordmanni, Sagitta bedoti, etc., occasionally together with subtropical oceanic elements such as Salpa fusiformis, Corolla spectabilis, Clausocalanus arcuicornis, Candacia bipinnata, etc. These animals are accompanied with the south-boreal neritic plankton flora consisting of Chaetoceros affinis, Eucampia zoodiacus, Lauderia borealis, Ceratium tripos, etc. and including some tropical-subtropical oceanic species such as Chaetoceros

4) In this connection, the situation off the west coast of Hokkaido merits a special attention. It has long been known that a phytoplankton community dominated by Coscinodiscus asteromphalus, a subtropical species, persists in the region from winter through early spring during the period of the lowest water temperature, sometimes reaching a great abundance, and it is usually at the end of March that it is replaced by the Chaetoceros-dominant blooming community (TANAKA 1947 ; IIzUKA et al. 1951; IIzUKA \& TAMURA 1953). Thus, it may be supposed that this region is transitional as regards the phytoplankton production sequence between the adjoining southern and northern regions; in the former region only the bloom of subtropical species is observed and never succeeded by that of cold-water species, while in the latter region the bloom of subtropical species is lacking and only that of arctic-north boreal species is recognized.

5) This copepod has been referfed with some doubt to Calanus finmarchicus or helgolandicus by most Japanese planktologists. BRODSkY (1948), however, separated it distinctly from the above Atlantic species under the name of C. pacificus, which was later splitted by the same author (BRODSKY 1962) into several species and subspecies. The present identification of the form occurring in the southern and eastern Japan Sea is after the view of CHEN (1964). 
peruvianus, Ceratium carriense and C. macroceros. These plankters appear there until about July, and their standing crops are generally insignificant (AIKAw A 1936 ; Shimomura 1957a; Meshcheryakova 1960).

In the western and northwestern parts of the sea, the bathypelagic zooplankton population turns to the decrease in late July or August (Meshcheryakova 1960; HeINrich 1961). Those zooplankters disappear from the shallower layers, partly by predation by macroplankton-feeding animals such as chub mackerel, saury and whalebone whales and partly by sinking into the deeper layers in the sea. And from this time till October or November, the shallower layers down to about $25 \mathrm{~m}$ are occupied by the populations of certain warm-water and mostly small zooplankters such as Calanus pacificus $(?=$ C. sinicus), Paracalanus parvus, Clausocalanus arcuicornis, etc., whilst the middle and deeper layers are inhabited by the immature and adult populations of bathypelagic Calanus cristatus and C. plumchrus (Meshchery Kova 1960). The standing crop is generally small throughout the summerautumn season there (Meshcheryakova 1954; Heinrich 1961). In Peter the Great Bay, temporary predominance of small neritic species, consisting principally of copepods of the genus Acartia, may be seen in August to October (BRODSKy 1941); and KUN (1954) found that Acartia longiremis, A. pacifica, Centropages abdominalis (=C. mcmurrichii), Evadne nordmanni, Podon leuckardti, etc., were constituting the chief diet of the 0-age chub mackerel caught in the bay in summer. A noteworthy fact of the plankton production in the summer-autumn season in the northern waters of the Japan Sea is the temporary growth in the population of Calanus glacialis, a form of C. finmarchicus s. lato, in the coastal areas along the northern Maritime Province and in the Tartary Straits. Due to the increase of this copepod, the standing crop of zooplankton attains its yearly peak in the season AugustSeptember in these regions; and this is considered one of the causes maintaining the summering populations of some migratory fishes, chub mackerel, saury and, in earlier days, sardine and squids in these northerly regions (Meshcheryakova 1960; Kondakov 1941; Kondakov in Sleptzov 1955).

From midsummer to early autumn, the plankton community of the southeastern Japan Sea is characterized by a rich occurrence of many neritic forms to a considerable distance from the coasts. The phytoplankton is represented mostly by neritic, boreal to tropical species of Chaetoceros such as affinis, didymus, lorenzianus and compressus (Fukase \& Furuhashi 1952; Shimomura 1957a; KARONJi 1957; etc.), and the surface planktonic fauna includes a large number of strongly neritic or embayment species such as Noctiluca scintillans, Sticholonche zanclea, Penilia avirostris, Evadne tergestina, cypriform larvae, Tortanus sp., Oithona nana, Sagitta crassa f. typica and f. naikaiensis, Oikopleura dioica, etc. (Tokioka 1951; Shimomura 1954a, 1954b, 1957b; Meshcheryakova 1960; etc.) 
The occurrence of these coastal forms in such an open part of the sea is never observed in other seasons. Refer also to Section 3.3. Rich occurrence of peridinians is another feature of the present season: temperate and neritic Ceratium tripos and tropical and oceanic C. macroceros and carriense occur sometimes in a large quantity, up to 30,000 cells per cubic meter (ShImomura 1957a). Along the offshore main stream of the Tsushima current and also in some nearshore waters such as the western entrance to the Tsugaru Straits, there often occur tropical and oceanic plankton populations, composed of Climacodium biconcavum, Biddulphia sinensis, Chaetoceros coarctatus and so on in plants, and Porpita umbella, Velella lata, Copilia mirabilis, Sapphirina spp., Corycaeus spp., Undinula vulgaris, Rhincalanus cornutus and so forth in animals (Shimomura 1957a, 1959 ; Karonji 1957 ; Nishimura 1958e; etc.). The occurrence of these tropical oceanic species is much strengthened since the latter half of October; and the range of the neritic plankters hitherto prevailed seems to have been shifted partly to the northwestern Pacific region through the Tsugaru Straits (see Bogorov \& Vinogradov 1955 and Brodsky 1955 for the prominent occurrences of warm-water neritic plankton in the waters lying east of the Tsugaru Straits, south of southeast Hokkaido and the Lesser Kuriles in summer, especially in September and October) and partly to the northern areas of the present marginal sea such as off Maritime Province and in the Tartary Straits. According to Meshcheryakova (1960), the northern limit of distribution of the bulk of those tropical oceanic plankters is found near the parallel $39^{\circ}$ or $40^{\circ} \mathrm{N}$. in the main region of the Japan Sea.

In November to December in the northwestern part of the Japan Sea, some cold-water species such as Metridia pacifica, Pseudocalanus elongatus and Oithona similis begin to appear and constitute the main part of the surface zooplankton biomass; and in coincidence with this, or somewhat earlier than this, an autumnal phytoplankton bloom, much smaller than the vernal one, seems to occur, consisting mainly of diatoms like Thalassiothrix longissima, Chaetoceros decipiens and the species of the genera Bacteriastrum and Stephanopyxis (Meshcheryakova 1960). The above-mentioned cold-water zooplankters are then, it is supposed, drifted south to the central and further to the southern parts of the sea and occasionally appear in the late winter to spring plankton just off the coast of north, middle and even west Honshu. Shimomura (1960a) showed that Oithona similis and Pseudocalanus elongatus were predominant species among the surface zooplankton around the migrating routes of the pink salmon Oncorhynchus gorbuscha over a wide area in the waters west of the Tsugaru Straits in May 1959, and according to Sнimomura (1957a), in 1952, O. similis was a most prevailing species in the zooplankton in the northern waters of Sado Island still in June, while Furuhashi et al. (1952) reported a dominant occurrence of this cyclopoid in the winter zooplank- 
ton off Wakasa Bay, west Honshu, being regularly observed during the years 1950 to 1952 . In midwinter (February), the northern Japan Sea is very poor of plankton; the phytoplankton is minimum and the zooplankton is also small, neither Calanus plumchrus nor $C$. glacialis is found in any mass quantity there (MESHCHERYAKOVA 1960).

From late October till January or February, the greater part of the southern and eastern Japan Sea sustains the poorest plankton biomass throughout the year, consisting, however, of quite diverse species, and despite of the water temperature approaching to the annual minimum, holding still tropical-subtropical and oceanic character: representatives are the plants like Ceratium and Rhizosolenia with their many species, respectively, and the animals like Calanus minor, Undinula darwini and vulgaris, Acrocalanus spp., Calocalanus pavo and plumosus, Eucalanus mucronatus and crassus, Centropages furcatus, Euchaeta marina, Labidocera acuta, Oithona plumifera, Sapphirina spp.,

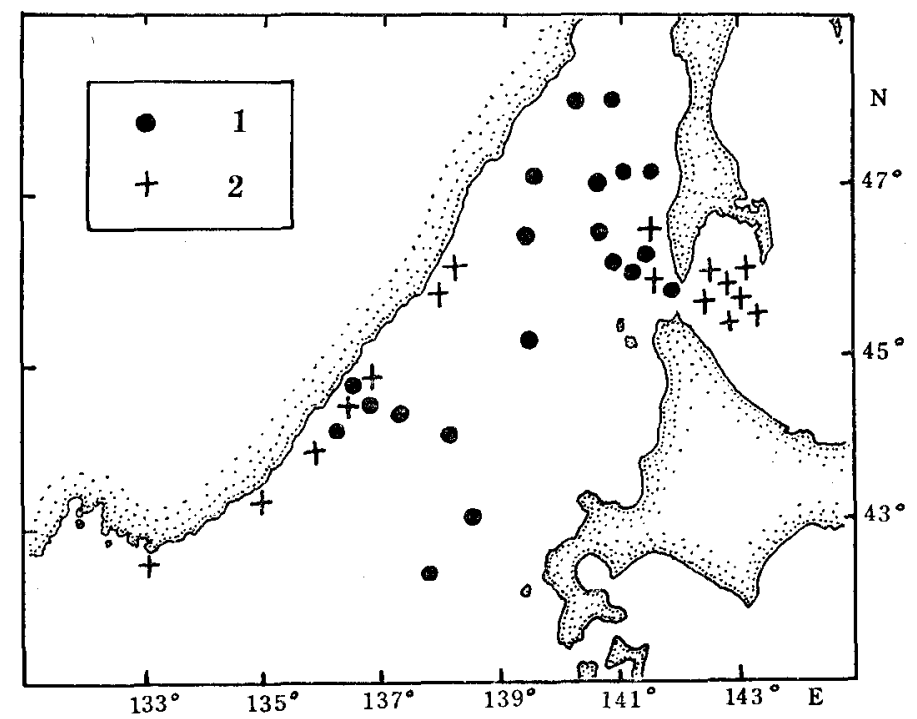

Fig. 17. Distributions of indicator plankton animals of the warm water and the neritic water in the northern part of the Japan Sea in January, 1950. 1.-Warm-water forms; 2.Neritic forms. (After Ponomareva 1954).

Corycaeus spp., etc., frequently together with the chaetognaths like Sagitta enflat a and minima; and no marked phytoplankton bloom is observed there. In the northern part of the Japan Sea, too, the occurrences of subtropical oceanic zooplankters such as Eucalanus attenuatus, Clytemnestra rostrata, Clausocalanus arcuicornis and Corycaeus sp. were noted by Ponomareva (1954) in a very wide area covering the offshore and coastal regions up to Nelma Bay in the Tartary Straits in January, while the neritic zooplankton is limited to a much reduced coastal area in this season compared with in the summer months (Fig. 17). Some of these warm-water species disappear as the water is 
chilled further, but others may survive till the next spring, especially in the southern part of the sea. In the plankton hauled in February in the offshore region of the southeastern Japan Sea, Meshcheryakova (1960) observed that some cold-water bathypelagic zooplankters such as Parathemisto japonica and Calanus plumchrus occurred together with warm-water species; $P$. japonica was represented by large populations of both young and adult, and $C$. plumchrus by all copepodite stages but especially by great populations of younger stages, suggesting that these bathypelagic zooplankters were in the breeding season. She also noted in the same material that surface warmwater plankters like Paracalanus parvus, Clausocalanus arcuicornis and Oithona plumifera were distributed, remarkably enough, down to the layers deeper than $200 \mathrm{~m}$.

Now the larval populations of the bathypelagic zooplankters will rise to the surface and, possibly maintaining shallow-water levels, will be drifted gradually toward the coasts of surrounding lands, notably middle to north Honshu and Hokkaido. In the shoreward drift, the species whose larval populations rise to the surface layers earlier may probably approach to the coastal waters at earlier dates than those of later breeding and larval rising. Thus, Nishimura \& OKachi (1957) and Nishimura (195Gb), studying the food of the chub mackerel wintering off the coast of Nigata on middle Honshu in 1957 and 1958, found that their diet consisted mainly of zooplankters like Parathemisto japonica and Metridia pacifica together with Euphausia pacifica in the earlier season (February to middle March) and that it was not until middle March and early April, respectively, that 5th copepodite larvae of Calanus cristatus and $C$. plumchrus appeared in large amounts to become the important food for the mackerel. Meanwhile, Furuhashi et al. (1952) reported that the zooplankters, chiefly copepods, collected in Wakasa Bay from January to February were composed mostly of oceanic warm-water elements, although smaller numbers of neritic or cold-water species (Paracalanus parvus, Oithona similis, Pseudocalanus elongatus, etc.) were mingled as well, and that none of the large bathypelagic plankton animals appeared in any great quantity and thus the standing crop was never raised highly until middle March.

\subsection{Seasonal Migrations of the Temperate and Subtropical Nektonic Animals}

Efforts have been made to clear the seasonal migrations of such fishes as chub mackerel, yellowtail, sardine and saury and other migratory animals like whales and squids for the reason of their great economical importance; and now a considerable amount of informations have been accumulated.

According to the view of Iто (1961), the sardine Sardinops sagax melanosticta seems to take a diffused pattern of northward migration after spawning: this clupeoid is supposed to pass the winter in a more or less deep layer of the waters south of Wakasa Bay, especially of the Oki Islands, and of the 
area off the southeastern corner of Korea, but to move into the coastal zone in early spring and then setting out the northward migration close along the coast the spawning is done in very nearshore zones in March to April in the southern area and in May to June in the northern area; the shoals having finished spawning are now considered to be dispersed to the offshore waters (Fig. 18a). In summer, the fish may be distributed over an extensive offshore area of the Japan Sea, but particularly, at the least in early years when the sardine population was large in the thirties of this century, in its northwestern part off Peter the Great Bay and the southern Maritime coast. The southward migration in autumn to winter seems to take place through dispersed offshore routes (Fig. 18b); and probably this makes the behavior of southward migratory shoals obscure.
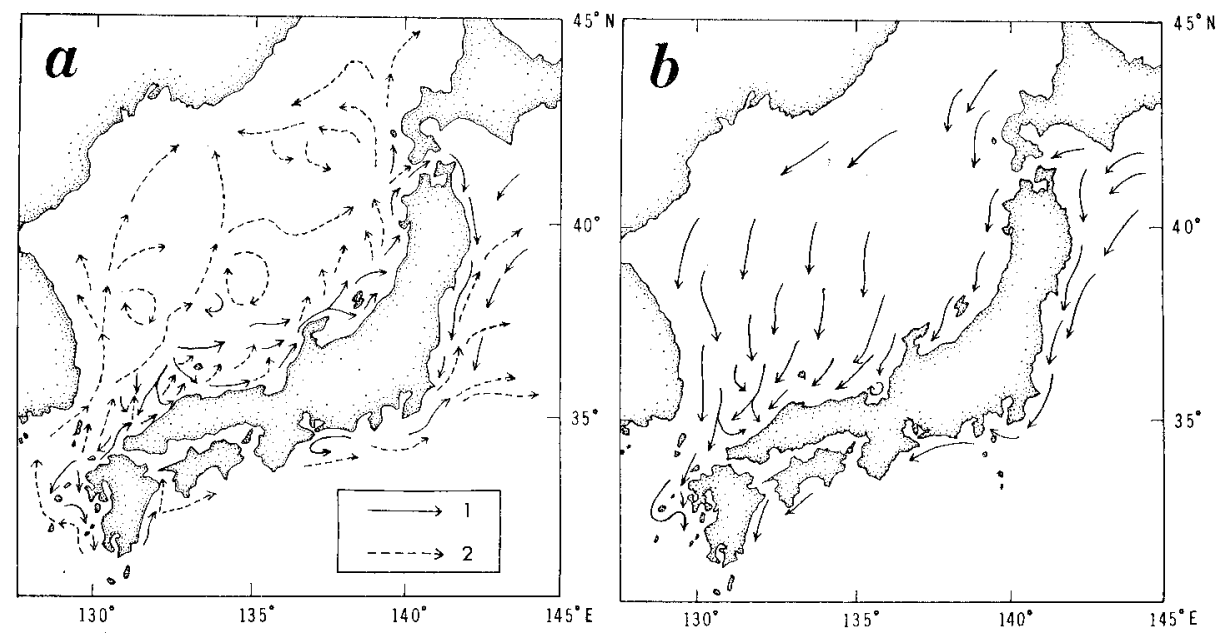

Fig. 18. Supposed migration routes of the sardine Sardinops sagax melanosticta in the Japanese waters (After ITO 1960; slightly modified). a.-Migration from spring to summer; 1.-Migration routes prior to the spawning, 2.-Routes after the spawning. b.-Migration routes from autumn to winter.

The saury Cololabis saira follows further offshore dispersed routes in both northward and southward migrations. The shoals move north in a much dispersed condition over an extensive area from April to August (Fig. 19), probably their main path being located in offshore waters, and thus they may be caught on the west coasts of islands such as Oki, Sado and Okujiri. Their summer habitat is confined to a narrow zone along the continental coast from northeast Korea to Maritime Province. The southward migration of saury in the Japan Sea is not well known as in the case of sardine, possibly because of their dispersed offshore routes. The regular appearance of saury shoals in late autumn to winter season (October through Februry) is confined to the 
regions around the islands and on the special coasts in the southern Japan Sea and the waters off northwest Kyushu, and these shoals are supposed mostly to have reached there straightly across the western half of the Japan Sea from their summer habitat (Fig. 19). The wintering quarters of this epipelagic fish are essentially limited to the southern part of the sea (probably south of Wakasa Bay and off the southeastern corner of Korea) and the

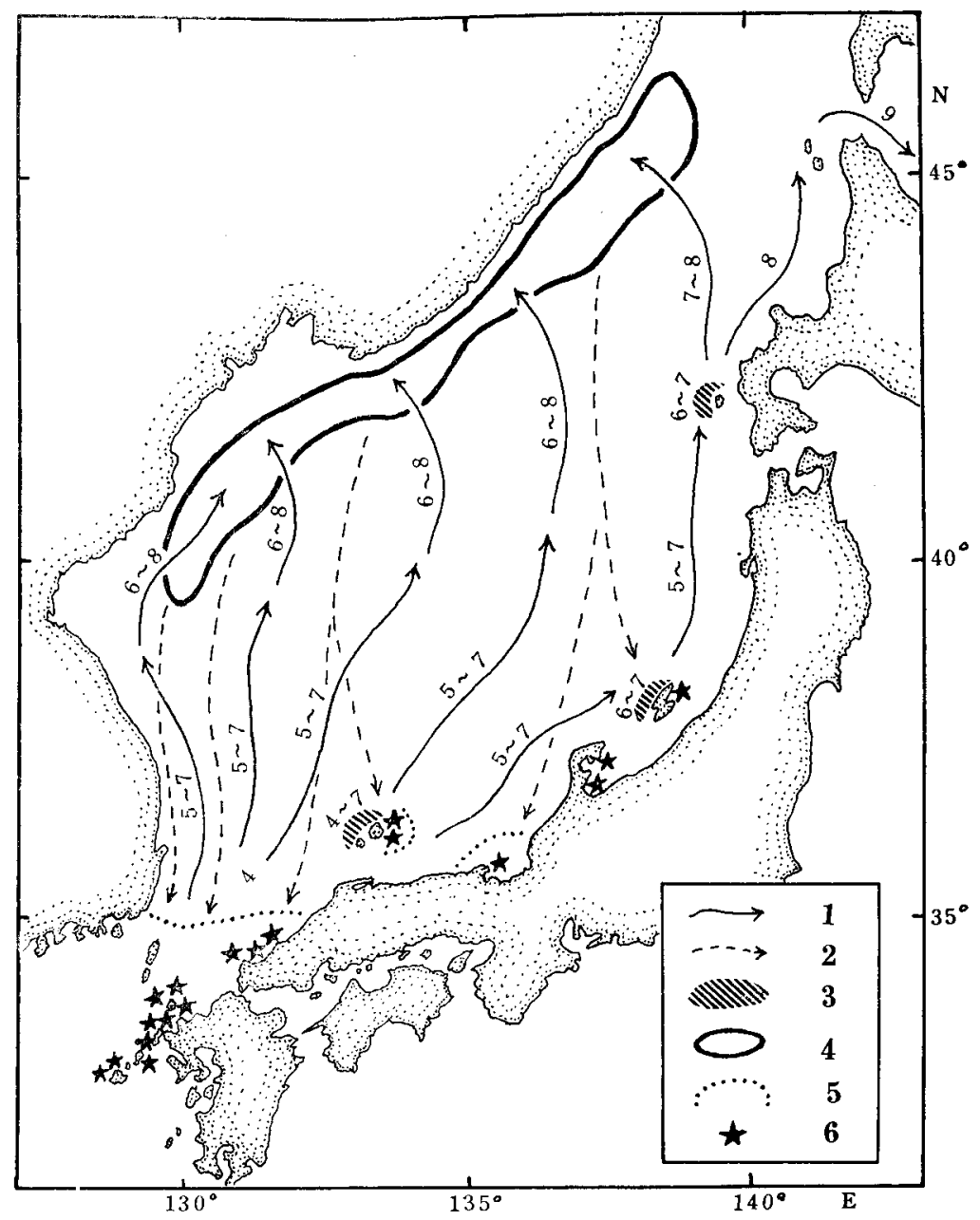

Fig. 19. Supposed migrations of the saury Cololabis saira. 1.-Supposed northward migration routes; figures indicate the month of res. pective migrations. 2.-Supposed southward migration routes. 3.Coastal fishing grounds for the saury in the northward migration. 4.-Summer habitat. 5,--Limit of the normal wintering place. 6.Saury is caught regularly (in the southern area) or occasionally (in the northern area) in winter. 
northwestern waters of Kyushu, but the greater portion of the population is considered to move into the latter (H. FuKataki, personal communication of February 1963).

Some species of whales seem to show a similar migration pattern. It was already suggested by $\mathrm{T}_{\mathrm{AGO}}(1922)$ that the gray whale Eschrichtius glaucus of the Far Eastern seas might take a straight offshore course from the northern coastal waters of the Japan Sea (the region near the Soya Straits according to TAGO; but it seems more likely that the whale starts the transthalassic migration from somewhere near Peter the Great Bay after passing through the Soya Straits and following down along the northern Maritime coast, as it is reported that the gray whale occurs off Peter the Great Bay in November to December but is never seen along the northeast and east Korean coast in that and subsequent seasons. See Tomrlin 1962) to its southernmost part, avoiding the coastal areas along east Korea or west Hokkaido to Honshu. Contrarily it was supposed to follow more or less nearshore routes along the continent (?and Japan) during the northward migration in early spring, March to May. The gray whale winters and breeds in the southernmost part of the Japan Sea, but especially in the waters off south Korea, the Goto Islands west of Kyushu and in the East China Sea. A similar migration was suggested by OMURA \& SAKIURA (1956) for the lesser rorqual Balaenoptera acuto-rostrata, which was once distributed in the Japan Sea rather abundantly, especially in Wakasa Bay in winter. And a similar pattern may also be true for the migration of the fin whale Balaenoptera physalus: the main route of its southward migration is considered to be located on the continental side of the Japan Sea, but peculiarly it is not found off the east Korean coast during this season suggesting the straight course from the southern Maritime waters to the southernmost part of the sea. Contrarily it is caught frequently on the east Korean coast during the season of its northward migration from March to May (TAGo 1922; MAtsuUra 1935a). The wintering area of the fin whale is supposed to be around the Tsushima Islands and in the Yellow Sea. Records of the whale stranding at Sado Island in the eastern Japan Sea seem to show that whales, possibly including species such as mentioned above, approached the island only on their way to the north when they were once abundant in this marginal sea, and this is suggesting that their southward migration routes in winter were offshore and crossing the central part of the sea (Nishimura 1961c). Moreover, there are evidences suggesting that these baleen whales, especially the lesser rorqual and fin whale, migrate rather dispersedly over a wide area in the sea not only following the coastal waters but also through its quite offshore part during their northward migration: it is not uncommon to observe these whales swimming around in small herds even in the central part of the Japan Sea 
during oceanographic cruises made in spring; and further, scrutiny of the occurrence pattern of whales at Sado Island (see above) has led NisHimurA (1961c) to the supposition that they are not necessarily confined to the very coastal waters during their northward migration. Thus, the general migration pattern of these whales in the Japan Sea may be schematized as shown in Fig. 20.

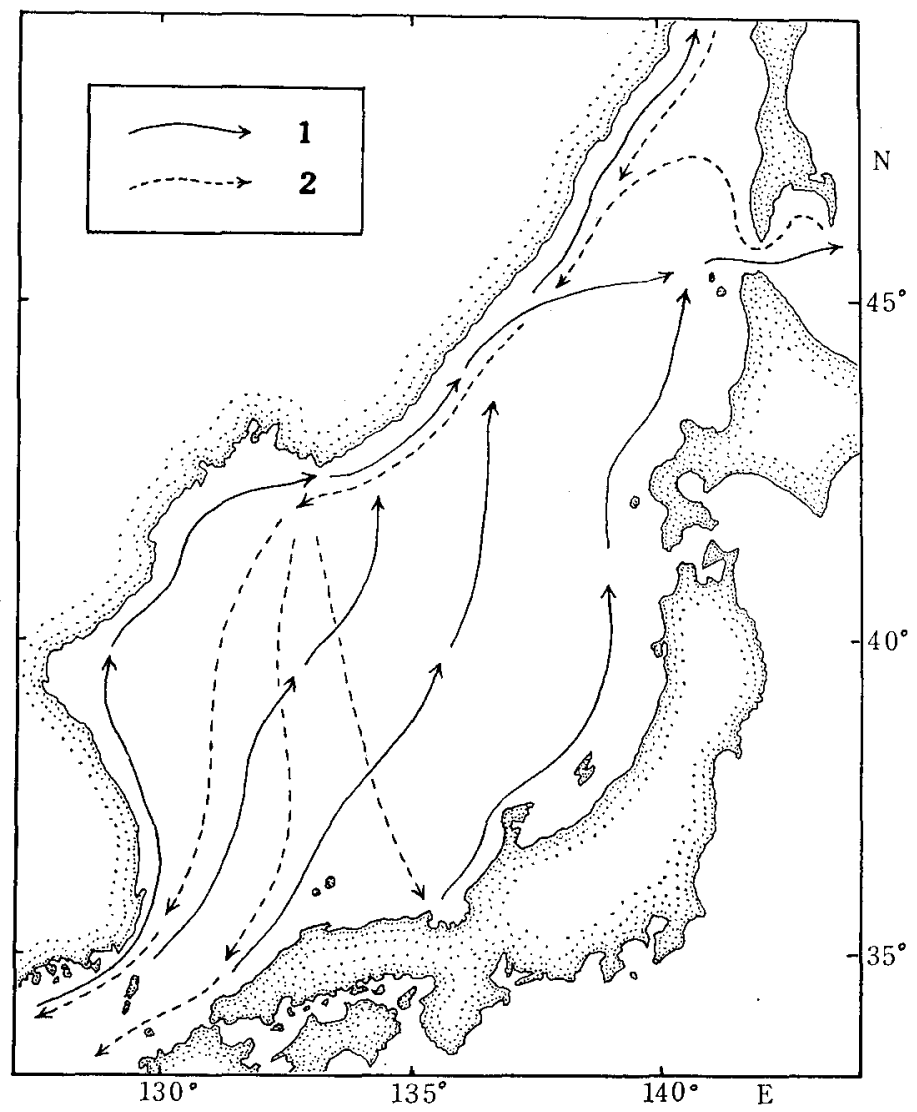

Fig. 20. Supposed migration routes of some baleen whales in the Japan Sea. 1.-Migration from spring to summer; 2.-Migration from autumn to winter.

Through the offshore fisheries experiments made by the Japan Sea Regional Fisheries Research Laboratory and other fisheries institutes in 1961-1963 and previous years, it has been definitely clarified that more or less dense shoals of the common squid Todarodes pacificus (=Ommastrephes sloani pacificus) are widely distributed in the offshore part of the Japan Sea, especially near the Yamato Tai Bank in the central part throughout the seasons from May to 
September (Fisheries Agency, Japan et al. 1962a, 1962b; OKIY AmA 1965 ; etc.). Although the biological properties of these squids found in the offshore area are not yet worked out sufficiently, it is supposed that they might be offsprings of the population which makes appearance and breeds in the northwestern waters of Kyushu in late September and subsequent season (the population is known as "higan-ika" or autumn equinoctial squid among the local fishermen ; see TANAKA \& IrzUKa 1956), and might have been transported to the central part of the Japan Sea in next spring (Fisheries Agency, Japan et al. 1962b). Actually I experienced to sight dense shoals of the youngs, mostly 5 to $8 \mathrm{~cm}$ in mantle length, of this squid gathering under fishing lamps and succeeded to dip some of them at many stations near the Yamato Tai Bank in late April, 1962; and it was supposed that the squids were distributed already widely and to considerable north by this date. Again in June, 1963, I observed the squid shoals distributed even in the far northwestern part of the sea, being compacted within the upper $25 \mathrm{~m}$ layer. On the other hand, it is stated by Russian authors (Kondakov 1941; Kondakov in Sleptzov 1955; etc.) that this squid is abundant in the northern Japan Sea from Peter the Great Bay to the northernmost part of the Tartary Straits, especially in that bay in June to September. Thus, it is estimated that a population of the common squid migrates north from its birth place in the west Kyushu waters into the Japan Sea probably in April through July or August and is dispersed over a wide area. And from September on the squids are considered to take the southward migration possibly through offshore course down to the region of the Tsushima Islands, where they may breed and then close their short, one-year life; TANakA \& Iizuka (1956) mentions that the immigration of the "higan-ika" population is observed only in the waters of the Tsushima Islands and never on the San'in coast.

The animals mentioned above, supposed to show a dispersed pattern of northward migration over an extensive area of the Japan Sea and again a more or less dispersed southward migration but mainly confined in the western half of the sea, are gathered together to be called as members of group $I$.

We shall next turn to the other category of migratory animals.

The chub mackerel Pneumatophorus japonicus shows three main routes of northward migration in the Japan Sea (KASAHARA \& ITo 1953): the first is the route along the west coast of Honshu up to Hokkaido and then into the Okhotsk Sea, the next along the east coast of Korea up to the Maritime Province, and the last across the central part of the Japan Sea from its southern area to near the west entrance of the Tsugaru Straits (Fig. 21). The mackerel is considered to winter in the coastal waters south of Niigata Prefecture as well as off San'in District on the Japanese side and around the 
Tsushima Islands and off the south coast of Korea on the continental side, generally at relatively large depths, 100 to $150 \mathrm{~m}$, near the botton until April or May (Kasahara \& Ito 1953; Nishimura \& OKachi 1957), then it goes up to the surface and sets out the northward migration through comparatively shallow layers. It seems that the shoals having wintered on the Japanese side (mainly in the regions of Niigata-Toyama Bay and around the Oki Islands) follow the coastal Japanese route, while the shoals having passed the

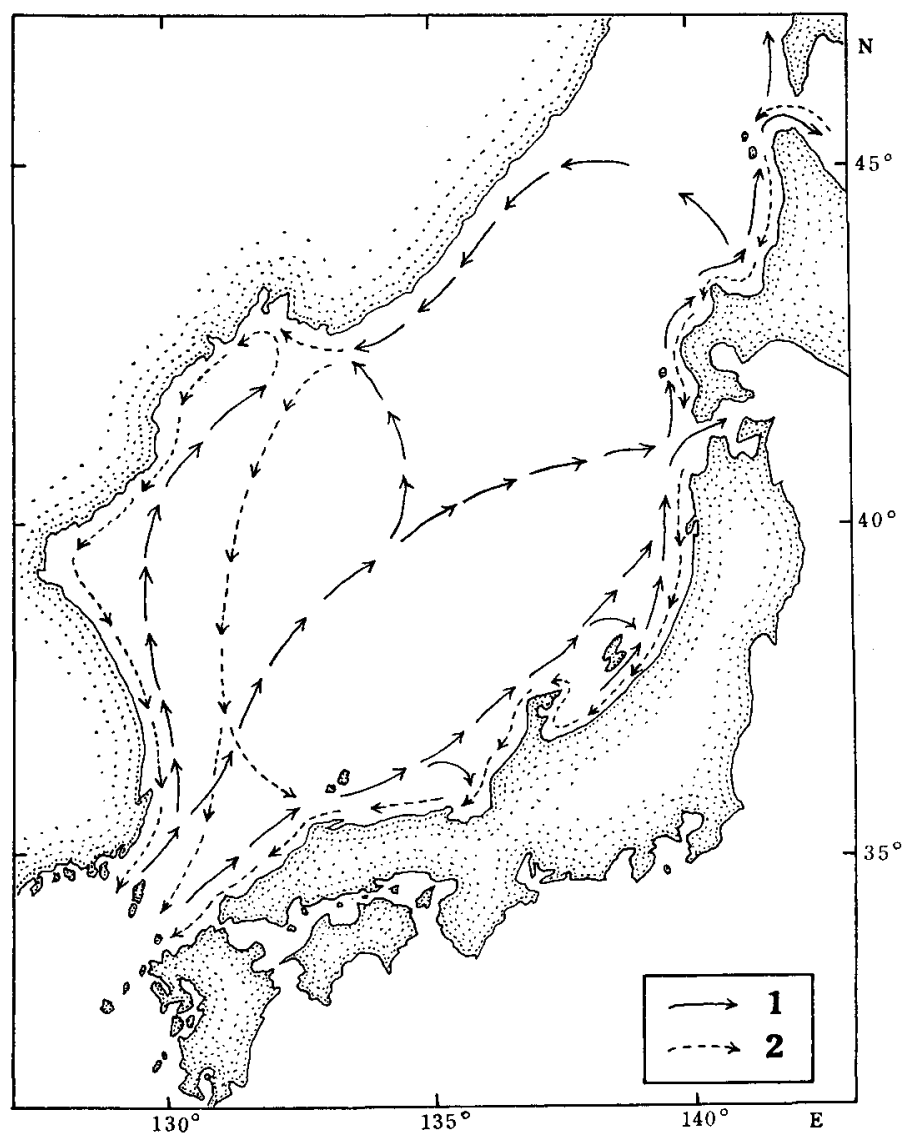

Fig. 21. Supposed migration routes of the chub mackerel Pneumatophorus japonicus in the Japan Sea. 1.-Migration routes from spring to summer; 2.-Migration routes from autumn to winter.

winter south of the Tsushima Islands take the central, trans-thalassic route as well as the continental coastal route. The migration seems to be done fairly rapidly during the period from May to July; in June a part of the populations appear off the west coast of Hokkaido, and they appear in the Okhotsk Sea and off Peter the Great Bay or the southern Maritime coast by 
July. During September to October, the distribution is extended north at the maximum; thus the fish is found mainly around Hokkaido, north Honshu and in the area from north Korea to south Maritime Province. Some shoals are, however, found still remaining during this season in certain southern areas, for instance, in Wakasa Bay and north of Sado Island; they may be contingents from the wintering place off San'in District and there they stay near the bottom, about 70 to $200 \mathrm{~m}$ deep (KasAHARA \& Ito 1953; Nishimura 1959b). In November the mackerel populations begin to move south and make appearance again in their wintering places in the southern waters by January. It is supposed that the shoals keep considerably deeper and more nearshore routes during the southward migration than in their northward migration, following clost to the edge of the continental shelf and banks.

The migration of the yellowtail Seriola quinqueradiata is similar fundamentally to that of the chub mackerel. This carangoid is said to winter in the region south of Niigata Prefecture and south of the southern coast of Korea and migrate north up to northwest and northeast Hokkaido in early summer (May to July) and come back again to their wintering places in late autumn to winter (November to January) (Mitani 1960; Kubo 1961; etc.) On the continental coast north to the southern Maritime Province, only the southmigrating shoals are clearly observed and there are evidences suggesting that the southward migration is commenced somewhat earlier than on the Japanese coast (Mitani 1959 ; Kubo 1961). It is peculiar that this fish is caught during the northward migration only at places of particular topography along the west coasts of Japan, that is, on the offshore side of the islands like Sado and Rebun and of the peninsulae such as Noto and Oga Peninsula, Cape Henashi-Zaki, Shakotan Peninsula, etc. and that the fish caught at these places in this season are composed almost exclusively of young ( 0 - to 2age) individuals. Contrarily, many large, sexually maturing (3-age or more) individuals are caught during the southward migration both along the Japanese and Korean coasts at places situated deep in bays such as Ryotsu Bay of Sado Island, Toyama Bay and Wakasa Bay and on the inshore side of certain peninsulae or of similar topographical conditions (Fig. 22). These facts possibly suggest that, as far as the adults are concerned, the yellowtail take during the northward migration an offshore route ${ }^{6)}$ against the more or less inshore route followed by young individuals, but they approach nearer the coast and even go into the inner part of embayments during the southward migration. In this connection, it is quite important to see that the main

6) MITANi $(1959,1960)$ is of the opinion that the yellowtail of the super-size over $11.45 \mathrm{~kg}$, caught exclusively but regularly on the west coast of Hokkaido in August to November, particularly in October, may belong to the shoals having travelled through the central part of the Japan Sea straightly from its southernmost region around the Tsushima Islands. 
spawning of the yellowtail is done in the waters southwest of Kyushu in March to June, mostly in April to May, and north of the same island in May to July (Shimomura \& Fukataki 1957; Mitani 1960), and thus the adult populations after spawning may appear in the southern Japan Sea possibly later than the young populations which stay and pass the winter in the same or southeastern part of this marginal sea.

The bluefin tuna Thunnus thynnus, a subtropical or rather south-boreal form, also takes different migration routes by ages (Окасні 1963): the adult and subadult (1-age or more) fish which may enter the southern Japan Sea through the Tsushima Straits in May to June or may have stayed there over

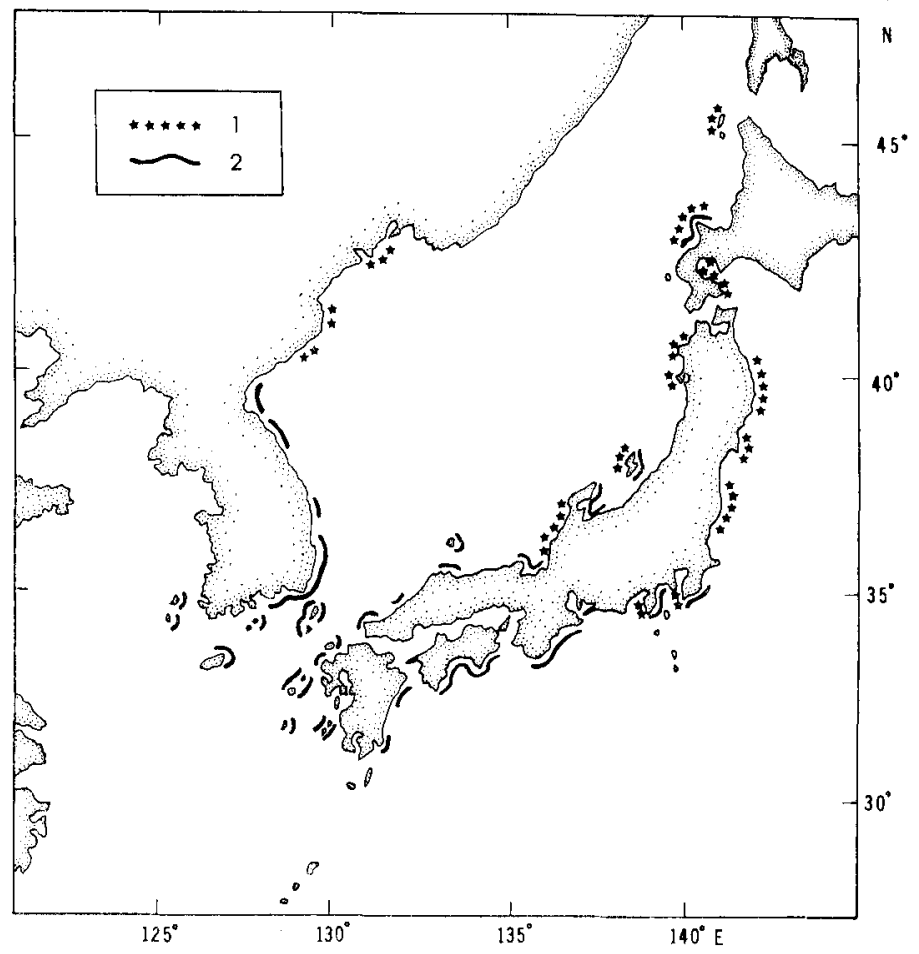

Fig. 22. Main fishing grounds of the yellowtail Seriola quinqueradiata in the Japanese and adjacent waters. 1.-For spring and summer shoals; 2-For autumn and winter shoals. (After Mitani 1960; slightly modified).

the winter are believed to migrate north mainly along the coast of Honshu and the majority of them, on reaching the northern district of this island, to pass through the Tsugaru Straits into the Pacific, while the young (0-age) fish entering the Japan Sea much later than the adult and subadult populations in midsummer are supposed to follow mainly an offshore course through the central part of the sea and to be driven south toward the Honshu coast 
in autumn and later season to be caught abundantly by set nets. Some shoals of these young bluefin tuna winter within the Japan Sea in the waters south of Niigata Prefecture.

Last, the frigate mackerel Auxis tapeinosoma, a genuine subtropical species, is considered to enter the Japan Sea in midsummer and to migrate north along a quite offshore route, thus it is caught only rarely in the coastal waters during this season; however, it is abundantly caught by set nets on the west coast of middle Honshu in late autumn to winter, suggesting a southward shift to the Honshu coast in its distribution after autumn (OKACH 1958). Although the majority of the frigate mackerel may be caught or go out of the Japan Sea to southern waters, some shoals evidently pass the winter within the sea, especially in Toyama Bay and Wakasa Bay, as they are found in these localities even in late winter. Thus, the migration of the frigate mackerel in the Japan Sea may be said quite similar to that of the porcupinefish mentioned previously (Section 3.2) as a typical example of the tropical pelagic animals driven into the Japan Sea by the warm currents.

The above species are common in showing more or less well defined routes, either coastal or offshore, during their northward migration and notably nearshore approach or abundant catch on the shore, at least on the Japanese coasts, during their southward migration; in these points they present a striking contrast to the species of group $I$ and therefore are to be called together as the animals of group II. The adult population of the anchovy Engraulis japonica (see Fig. 6, especially $h$ and $i$, for its seasonal occurrence in the Japan Sea) and the young and subadult populations of the jack mackerel Trachurus japonicus (Fukataki 1960b; Fukataki \& Watanabe 1960) may also belong to this group, although their migrations are not yet known sufficiently.

Summing up the above discussions, Fig. 23 is prepared to show schematically the principal differences in the pattern of seasonal migration between the pelagic animals of temperate and subtropical (groups $I$ and $I I$ discussed in this section) and tropical natures (discussed in Section 3.2 and may be called group III). And the following notes may be added:

(1) The northern limit of the wintering places on the Japanese side is located near Wakasa Bay in west Honshu for the animals of group $I$, but extended much north to Niigata Prefecture for those of group II. It is a notable fact that a prominent wintering habitat, other than that found in the southern part of the Japan Sea, is formed in the region from Toyama Bay to Nigata for many of the animals of group II. Meanwhile, it seems general for the animals of group $I$ that the majority of the population go out of the present sea in southward migration to pass the winter in the western waters of Kyushu or in the East China Sea. 

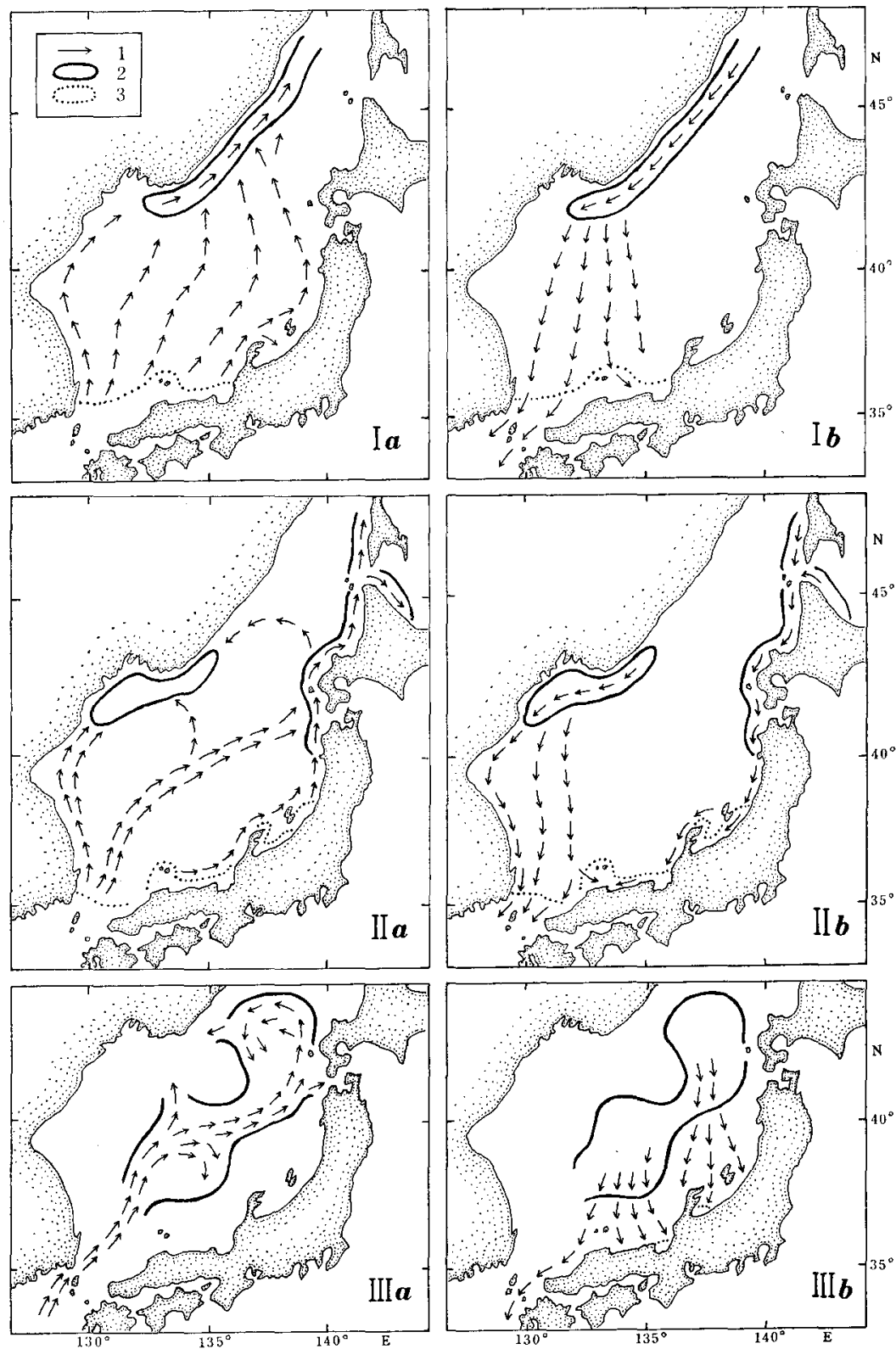

Fig. 23. Schematic representation of the seasonal migrations of temperate (I), subtropical (II) and tropical (III) pelagic animals in the Japan Sea. $a$ indicates the migration from spring to summer, and $b$ the migration from autumn to winter. 1.-Supposed migration route; 2 .-Summer habitat; 3.-Wintering place. 
(2) The northward migration is commenced much earlier in the animals of group $I$ than in those of group II, March to April in the former and May to June or later in the latter.

(3) Roughly speaking, the northward migration is of uni-origin in the animals of group $I$, starting their migration from a single, main source area in the East China Sea; but it is of multi-origin in the animals of group II, their migration being commenced generally from three source areas, namely, the Niigata-Toyama Bay, the San'in and the East China Sea region.

(4) A trend is noted for the northward migration of the group II animals that the later the season of migration, the greater the tendency to follow the central offshore route rather than the coastal routes.

(5) And this trend is culminated in the group III or tropical animals entering the Japan Sea in further later seasons.

Finally, a special mention is to be made that it seems more appropriate to regard these groups as complexes of populations different by ecology or developmental stages rather than to regard them as complexes of different species. Thus, the adult and subadult populations of the bluefin tuna belong to group $I I$ while its young population may rather fall into group $I I I$, and there are evidences suggesting that other than the squid population showing the migration pattern of group $I$ as mentioned previously in this section there are some populations of the same species that show a migration pattern of group $I I$ or even $I I I$.

[To be continued] 